

\title{
Teaching the "Bad Boy" to Write
}

\author{
Gary McPhail, Shady Hill School
}

From "In The 'Bad Boy' and the Writing Curriculum," by Gary McPhail, 2006. In Marilyn Cochran-Smith \& Susan L. Lytle (Eds.). Inquiry as Stance: Practitioner Research for the Next Generation (pp. 193-212). New York: Teachers College Press. Reprinted ${ }^{1}$ with permission.

\section{ABSTRACT}

In an attempt to address the gendered achievement gap in writing that exists both nationally and internationally, Gary McPhail conducted a year-long teacher research study focused on the gendered literacy interests of his first grade students and how they responded to a writing curriculum he created that included genres intended to be of interest to both boys and girls. This paper focuses on the experiences of one self-declared "bad boy" in Gary's class.

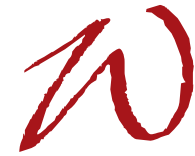

riter's Workshop is an approach to writing instruction, widely used in elementary schools across the country, which gives students the opportunity to reflect upon their own lived experiences, write about them during class time, and share them with their peers. In many primary grade classrooms, students spend the entire year writing personal narratives and honing the craft of writing by reflecting upon their own experiences. The underlying idea is that students learn to become authors of their own stories while they simultaneously acquire age-appropriate writing skills.

I have taught first and second grade for 11 years. Over these years, I have noticed that many girls seem to enjoy writing more and encounter greater success 
during Writer's Workshop than do many of the boys. As one of the few adult males working in an elementary school, this has always troubled me. Why don't the boys perform as highly as girls in writing? Equally as important, why don't the boys like Writer's Workshop as much as the girls?

\section{Gender and Writing Development}

When I began to research the intersection of the two topics of gender and young children's writing development, I quickly realized that the phenomenon of girls outperforming boys in writing was occurring all over the United States, not just in my classroom. Since the 1969 inception of the National Assessment of Educational Progress (NAEP), a standardized exam given to nine-, thirteen-, and seventeen-yearolds across the country, girls at all grade levels have scored much higher than boys in writing skills. Newkirk (2002) points out that the gap between females and males in terms of NAEP writing scores is comparable to the "achievement gap" between whites and other racial/ethnic groups that have long suffered systemic social and economic discrimination in this country. Furthermore, the gendered pattern of females outperforming males on NAEP scores is consistent across all racial/ethnic groups.

Much of the research on gender and writing suggests that boys and girls actually have differing literacy interests and prefer to write about very different topics. For example, Hunt (1985) found that elementary school age boys often wrote about sports, war, fighting, and catastrophes while their female counterparts wrote more frequently about themselves, their feelings, their families and friendships. Peterson (2001) found that the characters in girls' narrative writing demonstrated more emotion and pro-social behavior (sharing, helping, empathizing) while characters in boys' writing exhibited more aggressive behavior and engaged in more highintensity, dangerous actions. It is important to note, of course, that generalizations about differing literacy interests based on gender do not apply to the writing of all boys and all girls. Some boys like writing, and some girls do not. Some boys are interested in writing about their feelings, and some girls are interested in writing about aggressive behavior and violence.

However, a growing number of researchers (e.g., Dyson, 1997; Millard, 1997; Newkirk, 2002; Rose, 1989; Thomas, 1994) suggest that many schools cater writing curriculum and instruction to girls' learning and that boys are suffering because teachers do not acknowledge gendered differences in the writing preferences of 
their students. Along these lines, Newkirk (2002) argues that there is a hierarchy of genres in the writing curriculum across the country with personal narrative and poetry at the top and the genres that many boys prefer (e.g., comic book writing, action-packed adventures and nonrealistic fiction) near the bottom.

\section{Rethinking the Writing Curriculum}

When I was preparing to be a teacher, I was instructed to teach writing using the Writer's Workshop model based on the work of Donald Graves and others (Calkins, 1986; Clay, 2001; Dorn and Soffos, 2001; Graves, 1983). I became a firm believer in this model as a way for students to develop the necessary writing skills while also exploring and sharing memories from their own lives. The main idea here was that it was easier for young children to tackle the daunting task of writing a story when they were writing about their own experiences, mainly because these stories were their memories of things that had already happened. Literary components such as plot, characters and setting were already in place so young writers could simply focus on writing down their stories, casting themselves as the main characters. According to the traditional Writer's Workshop model, then, children would spend the school year writing personal narratives about themselves, their feelings and their own personal experiences. Looking back, I now realize that as a teacher candidate, I never questioned the idea that placing a large curricular emphasis on personal narrative might privilege some writers over others.

Since then, I have come to acknowledge that this writing instructional model biases certain literary interests over others. Many of the genres and styles to which many boys gravitate (e.g., comic books, adventure stories, silly fictitious stories, sports pages) are considered low status by many teachers (and parents) and are not welcome in many classrooms during writing time because they are either "inappropriate" for school or deemed not worthy of instructional time (Newkirk, 2002.) Thus many boys come to realize that their interests are not worthy of being taught in the classroom and as a result come to view writing as more of a female activity than male.

I decided that I owed it to my students to try something new and so I created a writing curriculum that included some units that I believed would be generally more appealing to boys and some that would be generally more appealing to girls throughout the year. I designed a revised Writing Workshop curriculum with a focus on different genres of writing as follows: 
September-October: Personal Narratives

November-December: Letter Writing

January-February: Comic Book Writing

March-April:Writing Fiction

May-June: Poetry

\section{David² as "Bad Boy"}

In this paper, I use David's experiences with the new curriculum to explore what happens when boys have the freedom and authority to write about their interests in class. In addition to documenting how David grew as a writer by connecting his own personal interests to the writing curriculum, I also show how important this connection was to David's social development. In fact, it was pivotal in his desire to transform his classroom reputation from a "bad boy" into an expressive and sensitive friend.

As a social member of the class, David was somewhat of a live wire who enjoyed testing limits and manipulating situations. He enjoyed his status as resident "bad boy" and had a powerful presence in the classroom. He pushed boundaries in order to obtain his rebellious classroom reputation. Image was very important to David. In addition to wanting to be known as mischievous and cool, he also desperately wanted everyone in the class to realize that he was intelligent, which he was. David was loud and animated. He loved an audience and occupied more classroom time than any other student. He once told me that it would be the worst thing in the world if people thought of him as dull. David was also obsessed with violence, which was an intense interest of his. He talked about it extensively throughout the school day to get attention from anyone who would listen. He depicted violence in his play at recess and often mentioned it during class meetings. He frequently made up stories and used violence to exaggerate these stories in class. He admitted that he purposely exaggerated in class and enjoyed being inappropriate. As his teacher, it was truly a challenge to figure out how to channel David's energy in appropriate directions. Throughout the year, I often talked with David about how to be a positive community member. David and I had a close relationship. He was a rather verbose, animated student, and partly because I gave him the attention he desired, he trusted me and we engaged in many conversations about his social and emotional development. At the beginning of first grade, David was often mean and disrespectful of classmates, particularly those he did not consider friends. From my perspective as a 
teacher, I perceived David as a child with a keen understanding of power who enjoyed exerting it over anyone who would let him. I liked David. Despite his desire for a rebellious reputation, he was a very funny and curious boy who loved learning and cared deeply about his social reputation.

Compared to his peers, David's behavior was extreme. It is important to note however, that there were "bad boys" like David in every class I have ever taught, and I suspect they are part of most primary classes across the country. Many primary grade classes contain more than one bad boy; they are simply a part of the classroom population. They enjoy pushing boundaries and seeking out attention in negative ways. At an early age, they define themselves as rebels. As a result they tend not to connect with the classroom culture or the curriculum in positive ways. They crave social acceptance but find pride in having a social identity that lies outside, or in direct opposition to, classroom expectations for appropriate behavior.

\section{The "Bad Boy" Abides by "The Boy Code"}

Early in the school year, David stood out to me as someone who struggled with embracing the personal nature of writing about himself. As a writer, he had strong skills and a solid working knowledge of how to sound out words. It was clear to me as a teacher that he was extremely bright, verbal and articulate. It was also immediately obvious, however, that David did not like the subject matter of writing personal narratives. He did not like figuring prominently in his stories and being the main character. Below are David's own thoughts about writing personal narratives.

It's not completely boring, it's not exactly the same as that. I mean, don't get me wrong, sometimes it can get really boring...but mostly it's just kind of hard. Not the actual writing part, but the "figuring out what to write" part. Sometimes I get headaches because I have to focus so much, and figure out what I want to tell everyone about myself. It just can get really tiring...

As a result, David was very hard to motivate during this unit. He spent the first several writing periods "thinking," which to me looked more like staring off into space or talking to other children.

When David finally decided upon a personal memory to write about, he did everything in his power to diffuse his own personal emotions out of it and to not 
focus on how he actually experienced the memory. For his first personal narrative, David wrote a story about saying goodbye to his mother at the airport when she left for Denver the first time. David's mother was in medical school and was going to do her residency in Denver, which meant that she was spending the year away from her family. An excerpt from my teacher research journal on this personal narrative is as follows:

\section{September 17}

The cover of David's story shows an airplane ascending into the sky. The illustration is done completely in black crayon. The title of the story is Sadness. The next step of writing a personal narrative [in our classroom] is to fill out a story web, in which students think about the following elements of their story: characters, main idea, setting, and story sequence (beginning, middle and ending.) Interestingly, after looking over the sheet, David wanted to fill out his story web alone. Towards the end of Writer's Workshop, David informed me that he was done, handed me his story web and began to walk away. I called him back and told him that I needed to review his work with him. In the box marked "characters" David had drawn a picture of the airplane and explained that this was the central character of the story. I asked if there were any other characters in the story. He looked at me for several seconds with a strong gaze and then replied, "Yes, my mother is on that plane." I said, “OK, then you need to write 'Mom' in the character box. After he did this, I asked him if there were any other characters in this story. He said "no." Then I asked, "Your title is Sadness. Who is the one feeling sadness in your story?" After a long pause he finally admitted, "Well...I'm the one feeling sadness... (and then softly) obviously." I replied by saying that he should write his name in the character box as well.

"But, I'm not focusing on me in this story, I'm focusing on my mother and the plane" he was quick to reply.

It struck me that David was trying desperately to diffuse the intensity of his sadness, the emotion that he chose to write about, by having his mom and the plane be the main characters instead of focusing on himself. He wanted his story to be told, he just didn't want to focus on his own feelings. I told him that next writing time we would work together to figure out how to do this but also on how to include his perspective into the story."Because it is a personal narrative and writing about yourself is what 'personal' means" I said. His somber look showed me that he understood. 
During the next few days, it became even more clear to me that David did not want to elaborate how he actually felt about his mom being away beyond the poignant (and even powerful) title he gave his narrative--'Sadness.' "Isn't it obvious?" he would say. I had to agree with him. It was, very. David wanted the creative freedom to tell the story his own way. He wanted to diffuse the intensity of his own sadness-remove it from his personal narrative. This story was important enough to David that he wanted to write about it, but he was very clear in that he did not want to focus on his own sadness because doing so might tarnish his reputation as the resident bad boy. David was taking a risk in sharing this story with the class and I was proud of him for choosing this personal event. I did not want this process to be more emotionally charged for him than it already was, so eventually I gave David permission to tell his story his way. His final version is as follows:

\section{SADNIS $^{3}$}

ONSE MOM HAD TO GO LIVE IN DENVER. I COODINT GO MY MOM ROD A JETPLAN TO DENVER

HER APARTMENT WAS SMALL

IT WAS COOI BECASe it had a MAIL Slot

SHE HAD A BALCONY. SHE SAID THE SIGHT WAS beautiful

BUT SOMETIMES IT WAS COLD.

THERE WAS A MAIL SLOT

THERE WAS A GARBAGE chute

THERE WAS VACUMING TO DOO!

Then it was time to go! No!

\section{(Sadness}

Once Mom had to go live in Denver. I couldn't go.

My mom rode on a jet plane to Denver.

Her apartment was small.

It was cool because it had a mail slot.

She had a balcony. She said the sight was beautiful.

But sometimes it was cold.

There was a mail slot.

There was a garbage chute.

There was vacuuming to do!

Then it was time to go! No!)

When reading David's story, complete with illustrations, I could feel David's sadness but his actual writing did not tap into his own feelings about his mother liv- 
ing away from him. This was a deliberate decision on David's part. Although he wanted this story to be told, he was not comfortable expressing his sadness outright, especially since others would be reading this story. This connects with what Pollack (1998) says about boys not being comfortable talking about their lives and their true emotions. He states that many boys are in a gender straight jacket because they feel it is not okay to express emotions because they must present a strong, stoic front. Instead of revealing their true emotional side, they learn at an early age to abide by what Pollack calls "the boy code" and to hide behind a mask of masculinity. Boys who abide by the boy code, boys like David,

often are hiding not only a wide range of their feelings but also some of their creativity and originality, showing in effect only a handful of primary colors rather than a broad spectrum of colors and hues of the self ( $p .7$ )

Once David figured out how to diffuse the emotional intensity out of what was a very important experience to him, he wrote a strong piece. Protecting his emotional vulnerability, and saving face, he was still able to embrace the process of writing about a personal story and share it with the class in a way with which he felt comfortable.

\section{Deconstructing the "Bad Boy"}

When the writing curriculum shifted from personal narratives to letter writing, David was more motivated to write. In this unit, writing became a meaningful form of social interaction for him. David wrote seven letters in one month, compared to one personal narrative in two months. Knowing that we were about to start writing letters but before I even taught the first mini-lesson to the whole class, David took the initiative during morning choice time and wrote the following letter to his friend Michael:

DERE MIKL-

SPY SUPLIS IS SO GRET!

I THINC THAT YOU ARE SO GRET!

WE WILL MEET AT THE BLOK AREA TOOMORO OK?

DOBLO-O AGENTS 005

SINSIRULY

DAVID

P.S. I LIK YOU! 
(Dear Michael,

Spy Supplies is so great!

I think that you are so great!

We will meet at the Block Area tomorrow, OK?

Double 0 Agents, 005

Sincerely,

David

P.S. I like you!)

David was extremely attentive and excited throughout the unit on letter writing. He liked that there was a very specific and private audience for his thoughts. Personal narratives were read by the class at large, but with letter writing David was in control of who would read his letters. He enjoyed having this level of control as a writer. The lines "I THINC YOU ARE SO GRET! " and "I LIK YOU!" really stood out to me. As a social member of our class, David had a very hard time giving compliments to other students. Instead of being nice, he often hurt other people's feelings. It struck me that one of the first times I saw David take the initiative to compliment someone was in the form of a private letter. There was an audience of one in letter writing, and David did not have to worry about his public image. David wrote this letter to Michael to tell him that he liked him as a friend and wanted to keep playing with him. Letter writing provided a safe, private forum for him to do just that. David used letter writing to strengthen relationships with chosen friends. Ironically, he revealed more about himself personally and felt more comfortable expressing his true emotions through writing during the letter writing unit than he did during the personal narrative unit mainly because he was in charge of his audience. He could maintain his "bad boy" reputation with the group at large while strengthening specific friendships and reaching out emotionally to those he held dear.

David's interest in writing peaked during the comic book and fiction units, primarily because these units allowed David to depict violent scenes in his writing, but within established parameters. He informed me that he liked incorporating violence because he thought it made his writing more exciting. He stated,

I do it because I don't want them to like, start telling everyone David's comic book is really boring. David's comic book isn't exciting at all. I don't want them to think I'm dull so I get violent to get their attention. 
Similar perhaps to the reasons David behaved aggressively on the playground, he created violent comic books so his classmates would not consider him dull. David also wanted to be known as smart. The following excerpt from my teacher research journal shows how David learned to portray himself as both intelligent and interesting by utilizing violence in his writing:

January 15

On day one of our comic book unit, David started illustrating a very violent scene. He was working on a comic strip that featured a crime-fighting character that battled bad guys. Every character in the opening illustration had multiple guns and knives. Some of the bad guy characters were drawn with cut marks on their bodies. David's first draft of this illustration was very grotesque and he looked forward to having people think it was either disgusting or inappropriate. Feeling very proud of his violent scene, he ran right over to James, a $3^{\text {rd }}$ grader who comes to the classroom to help during Writer's Workshop. James, who also enjoyed an occasional violent scene, told David that he liked the idea of this comic character but that there was a certain way to illustrate violence in comics and that it wasn't cool to show the goriest, grossest picture. As they were talking about this, I overheard James say to David, "As the author, you have to get creative. Remember, you have the power as the creator of the comic. Don't go overboard. Make the reader work for it a little. Give them a little bit, but leave a lot to the imagination for the reader.That's the sign of a good comic creator."This spoke volumes to David. It was very important for David to be portrayed as smart and James, a big kid in David's eyes, was telling him how to be smart about depicting violence in his comics. What could be more important and meaningful to David?

Using the old Batman comics as an example, I instructed James to explain how comic writers draw a cloud of smoke (possibly with a head or a foot sticking out around the perimeter) with the words like BANG or KAZOW written over the cloud. That way, you could include violence in the writing but you don't go overboard drawing it. David loved learning this strategy, especially since it came from a big kid that he respected. Halfway through Writer's Workshop, James had to return to his own class. After he left, I watched David turn to Hunter and explain how to depict violence in his comic. David recited verbatim what James had told him. 
There was real power in David's realization that there was a smart way to depict violence in his comics. He understood that the authors of comic books and fiction stories have a lot of power and creative control. Power and control were extremely important to David. He stated many times that he found it "freeing" to write fiction and comic books and he liked that the subject matter wasn't directly personal.

As a teacher, I learned a great deal about David's personal development by observing him and paying close attention to what he wrote about during these units. David was obsessed with violence, and he was glad that this was not a taboo topic for Writer's Workshop during these genres. He depicted violent scenes in every comic book and fiction story he wrote. Even though violence was not an interest of mine, and one I hoped he would soon abandon, David connected this interest to the writing curriculum. He was fascinated by the guidelines (such as using the cloud and words like "Zowie" to disguise the gore) for incorporating violence into comic books. He abided by them, for the most part, because these strategies made him feel intelligent and creative as a writer.

Importantly, because violence was a personal interest of his and not considered a taboo topic for writing, David made personal growth by incorporating this interest into his writing and sharing his thoughts with his peers. Prior to this time, David had used violence to rebel, to shock, and to get attention. Once the topic of violence was included in the curriculum, David did not rebel or act out as much because his interests were connected to the curriculum. Importantly, I learned more about David by watching him while he wrote about topics of interest to him. By listening to what he had to say and observing his behavior when there was violence in his writing, I learned that David incorporated violence in his drawings and his play when there was something emotionally upsetting in his life--his mother living in Denver, his best friend lan moving to Brazil, his feelings of exclusion by some of his friends, his father working too much. Throughout the year, David and I often engaged in talks about social issues that were important to him and violence was a common theme that weaved together many of these conversations. I realized that there was usually a strong connection between David's depictions of violence in writing and his social life. The following excerpt from my teacher research journal explains the social ramifications of this very important point:

June 27

Many of the students in my class have expressed that it scared them when David talked about violence, wrote about it, or pretended to act out something violent. Even his close friends were beginning to think that his obsession with violence was inappropriate for school. 
lan is one of David's best friends. At the beginning of the year, lan found it fascinating that David knew so much about violence, war and catastrophe and sought out David's friendship. During the winter months, David became even more obsessed with violent movies and TV shows and he gained popularity with lan as a result. Talking about violence and including violence in his writing and play became a way for David to connect with lan. During the spring, things began to change, however. lan began to move away from David because of his violent tendencies. During the early spring months, it was noticeable that David was being increasingly rude to many of his friends and was drawing and writing more violent pictures of war and bombings. David also became more physical during games out on the playground like "Cops and Robbers." Ian began to pull away from David because he felt that David was spending too much time drawing, writing and talking about violence and disasters. It scared him. When he began pulling away, lan began to really feel David's wrath. David told lan that he hated him and that he wasn't his friend anymore.

After talking with David and observing his behavior for a while, I realized that David was actually upset because lan was moving away to Brazil for a year. And although lan was coming back in third grade, missing someone for a year is like an eternity when you're in first grade. David had grown close to lan and now he was moving away. David was acting out because he was upset and he was channeling his anger in the only way he knew how to: by using violence in his play, writing and drawing to get attention. At that point, I realized that David's use of violence had become a social barometer I could use to know how he was feeling.

I asked David if he wanted to have "a private meeting" with lan to discuss how he was feeling. In this meeting, David explained that he was feeling confused because he felt that earlier in the winter he had been drawing more violent pictures and talking about violence to strengthen his friendship with lan. But now, lan was pulling away because of the violence. It didn't make any sense to him. David expressed this to lan and in turn lan acknowledged that he was indeed purposely pulling away from David. "I don't like it anymore when David gets obsessed with violence and I don't want to go down a bad road myself and get in trouble. I don't want to be known as a bad boy like David," he explained. lan expressed that he used to be more interested in violence but he felt that he had outgrown it. "People grow at different rates," lan explained "and sometimes people are just latebloomers about some stuff. And maybe David is just a late-bloomer about 
outgrowing violence." Instead of being upset about this, or even insulted, David nodded and accepted this rationale. David then told lan that he was going to miss him while he was away. This made lan smile and they spent the remainder of the recess devising a strategy to communicate with each other via their parents' emails using a secret code.

Similar to how I realized that my students' personal narratives could be considered windows into self, by using David's overall writing throughout the entire year as a window into self, I gained tremendous insight into his personal life. He used violence to communicate his emotions, and I believe he desperately hoped someone would pay attention. I realized I could use his depictions of violence as a social barometer to monitor how he was feeling emotionally without David having to state it outright. His actions spoke louder than his words.

In this way, David revealed a great deal more about his personal self during the letter writing, comic book, fiction and poetry units than he did when the curricular focus was on personal narratives. The real impact of David's social and emotional growth as a result of being able to connect personal interests (in this case, violence) with the writing curriculum was truly felt during our poetry unit at the end of the year.

\title{
David abandons the "Bad Boy" Stance
}

The following is a poem that David wrote the very next day after the conversation with lan when he told lan he hated him and that he was not his friend.

\author{
NO War \\ by DAVID
}

War is crazy, war is dumb. If war dozeNt stop I'LL eat MY thumb. Gun's are dangerous and no fun, I'm out to make WaR say GOODBYE. if I fail I'LL Pobably CRY.

HurrAY! I did it! YippY ME! Earth is pecefulk cause of me!

\section{No War \\ by David}

War is crazy, war is dumb. If war doesn't stop, I'll eat my thumb. Guns are dangerous and no fun.

I'm out to make war say "Goodbye." If I fail, I'll probably cry.

Hurray! I did it! Yippy me! Earth is peaceful because of me! 
The picture that accompanied this poem depicted David and lan, smiling and holding hands, standing on top of the Earth with a big rainbow overhead. When he was done, he walked around the class and shared the poem with anyone who would listen. This was a social breakthrough for David. Along these lines, Gallas (1998) said that "bad boys, like most children, are not naturally mean spirited; they are experimental. They are small, social scientists studying the effect of their behavior on others" (p. 44.). David was one such social scientist who experimented with violence throughout the year as a way to communicate his emotional state to others.

In his poem, No War, David not only took an anti-war stance but he also publicly displayed affectionate feelings of friendship towards lan. This was in stark contrast to David's behavior at the beginning of the year when he was consistently mean to the majority of his peers. By writing this happy anti-war poem, David allowed himself to be vulnerable and showed his classmates that he was kind and that he wanted to change his reputation as resident bad boy. This social transformation took time but by the end of the year, when our poetry unit took place, David managed to break out of his emotional straight jacket and abandon the boy code.

It is important to note that if the writing curriculum had not been able to connect with David's interest in violence, he would not have been able to write about this interest freely, which contributed to his desire to change his social reputation. By being more inviting, the writing curriculum helped David rebel less against the classroom culture and become more interested in Writer's Workshop.

\section{The Bigger Picture}

David showed me that he had different literacy interests from those that are the focus of the traditional Writer's Workshop model. In fact, many boys in my class were similar to David in that they were not interested in writing personal narratives. When I opened the door and widened the circle of acceptable writing topics, most boys felt more connected to the writing curriculum and readily brought their literacy interests in. Their interests included fantastic intergalactic battles of good vs. evil, imaginative stories about being a coach of an NBA Dream Team, gory poems about haunted houses, personal narratives about being kicked in the crotch, and letters to Rudolph the Red-Nosed Reindeer. These interests were not always appropriate and did not always focus on topics in which I was particularly interested. They were, however, of interest to these boys, and when they were allowed to pursue them, they wrote freely and willingly. 
For the most part and with some exceptions, the boys and girls in my class tended to have differing literacy interests. The girls tended to prefer to write personal narratives and poetry while the boys tended to prefer to write comic books and fiction. What is most important about my study overall, however, is that both boys and girls performed at higher levels when writing in genres that were of interest to them.

If there are indeed differing gendered literacy interests among many young children, then would it not serve us well as educators to further investigate our approach to writing instruction? Perhaps we should offer a writing curriculum that includes a wide array of genres, including those that often tend to appeal more to boys or more to girls, especially if this shift will help many boys be more interested in writing. I wonder if the bad boys in primary classrooms across the country, boys like David, may feel more connected to the classroom culture when the writing curriculum is connected to their own interests. I have known many boys who are not interested or able to readily process their emotions, reflect, or talk about their personal lives with great ease or willingness. Should this have to impact their writing development as well? By shifting the content of what we teach, and by diffusing the personal from the curriculum, I believe these boys can learn how to write and use this skill in a socially meaningful way that helps them connect writing to their own interests, as different as they may be.

\section{Notes}

1. The reprinted article has been shortened and edited for purposes of the LEARNing Landscapes journal.

2. All names are pseudonyms.

3. I present and translate my students' writing exactly as they created it. The words I present are theirs. The texts I present are exactly the same as the writing they produced, with the exception for some key words that were changed to protect the anonymity of the child. 


\section{References}

Calkins, L. (1986). The art of teaching writing. Portsmouth, $\mathrm{NH}$ : Heinemann.

Clay, M. (2001). Change over time in children's literacy development. Portsmouth, $\mathrm{NH}$ : Heinemann.

Dorn, L., \& Soffos, C. (2001). Scaffolding young writers: A writers' workshop approach. Portland, ME: Stenhouse Publishers.

Dyson, A. H. (1993). Social worlds of children learning to write in an urban primary school. New York: Teachers College Press.

Gallas, K. (1998). "Sometimes I can be anything": Power, gender and identity in a primary classroom. New York: Teachers College Press.

Graves, D. (1983). Writing: Teachers and children at work. Portsmouth, $\mathrm{NH}$ : Heinemann.

Hunt, B. (1985). A Leprechaun in King Arthur's Court: Topic, Theme, and Mode in the Writing of First Graders Using Invented Spelling. Reading Research Quarterly, 10, 74-75, 103-123.
Millard, E. (1997). Differently literate: Boys, girls and the schooling of literacy. London: Falmer Press.

Newkirk, T. (2002). Misreading masculinity. Portsmouth, $\mathrm{NH}$ : Heinemann.

Peterson, S. (2001). Gender Identities and SelfExpression in Classroom Narrative Writing. Language Arts, 78(5) 451-457.

Pollack, W. (1998). Real boys: Rescuing our sons from the myths of boyhood. New York: Holt Publishing.

Rose, M. (1989). Lives on the boundary: The struggles and achievements of America's underprepared. New York: Free Press.

Thomas, P. (1994). Writing, Reading \& Gender. Gifted Education International, 9(3) 154-158.

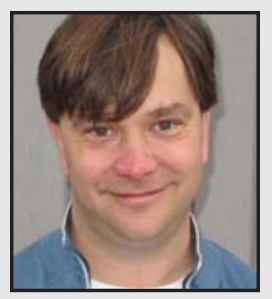

Gary McPhail teaches first and second grade at Shady Hill School in Cambridge, Massachusetts. He has taught in the primary grades for 11 years. He is also an adjunct professor at Boston College where he received his doctorate in 2008.

Gary is currently leading a group of teacher researchers featuring one teacher from every grade level at Shady Hill. This group is inquiring into their own practice and working to create a school-wide writing curriculum that is of interest to a variety of young, budding writers. 